\title{
Trendy v české intervenční kardiologii
}

\author{
Josef Veselka \\ Kardiologické oddělení Kardiovaskulárního centra, Fakultní nemocnice v Motole, Praha, Česká republika
}

Adresa: prof. MUDr. Josef Veselka, CSc., FESC, FSCAI, FICA, Kardiologické oddělení Kardiovaskulárního centra, FN v Motole, V úvalu 84, 15000 Praha 5, Česká republika, e-mail:Veselka.josef@seznam.cz

Prof. Lanzer naznačil ve svém editorialu obecně platný kardiologický trend „od umění k řemeslu“. Ten jednoznačně platí i v České republice. Počet perkutánních koronárních intervencí (PCI) se zvýšil v dekádě 1996-2005 čtyřnásobně, přičemž v posledních čtyřech letech se jejich počet významně nemění. Generace mladších invazivních kardiologů, kteří jsou však dnes již ve středním věku, byla hlavním hnacím motorem tohoto dynamického růstu a skutečně přešla od umění menšího počtu zajímavých a někdy spíše intuitivně vedených výkonů k řemeslu bezpečné intervenční kardiologie s průměrným počtem 1000 PCI na jednu katetrizační laboratoř ročně. Umění je krásné, ale řemeslo založené na zkušenosti z tisíců výkonů je lepší. Velký dík patří našim učitelům, že jsme mohli na jejich práci navázat.

Druhá polovina 90. let minulého století byla ve znamení diskusí o správném postupu u nemocných s akutním koronárním syndromem. Dodnes se tyto diskuse vedou, i když na půdě české intervenční kardiologie již méně. Důvodem je všeobecné přijetí agresivního způsobu léčby u těchto nemocných, podpořený dobrou časovou i geografickou dostupností katetrizačních laboratoří po celém území naší republiky a jejich 24hodinovými příslužbami pro nemocné se STEMI. Již léta neléćíme nemocné se STEMI trombolýzou a pacienty s nestabilní anginou pectoris klidem na lůžku a kombinací beta-blokátorů, nitrátů a antitrombotik. Nikdo z nás nepochybuje, že je to tak dobře.

Jestliže jsme stále pevněji přesvědčeni o prospěšnosti katetrizačních intervencí u nemocných s akutními koronárními syndromy, pak podobný postup u nemocných s lehčí formou stabilní anginy pectoris přináší rozporuplné výsledky. Výsledky studie COURAGE, ${ }^{(1,2)}$ jakkoli diskutované a různě interpretované, přinesly do myslí intervenčních kardiologů oprávněnou obavu, zda všem našim pacientům s chronickou formou koronární nemoci poskytujeme skutečně optimální léčbu.

Diskuse o potřebnosti koronárních intervencí se vedou i v souvislosti s terapií chronických koronárních uzávěrů.
Je nepochybné, že chronicky uzavřenou věnčitou tepnu bychom se měli snažit otevřít v případě, že je zdrojem jasné limitující anginy pectoris nebo zásobuje rozsáhlé povodí viabilního myokardu. Klinická praxe není však jednoduchou učebnicovou poučkou, takže stanovení individuálního poměru rizika a ceny intervence $\mathrm{k}$ rozsahu viabilního myokardu či hranici tolerovatelnosti anginy pectoris je skutečně velmi těžké.

Pozitivní zprávy o lékových stentech nás před několika lety vedly ke značnému optimismu z hlediska rozšíření PCI i na pacienty, které jsme do té doby léčili pomocí chirurgické revaskularizace. S odstupem několika let vidíme, že i lékové stenty přinesly svá nečetná, avšak klinicky nezanedbatelná rizika (pozdní trombóza a velmi pozdní trombóza), a recentně publikované dvanáctiměsíční výsledky studie SYNTAX ${ }^{(3)}$ ukazují, že u pacientů s chorobou tři tepen nebo stenózou kmene levé věnčité tepny, je chirurgická léčba stále metodou první volby. Zda je tomu tak u všech pacientů, a jaké jsou skutečné preference nemocných, je otázka jiná. Nesmírně zajímavé je i zjištění studie SYNTAX, že osud nemocných s vyšším SYNTAX skóre (parametr rozsahu postižení věnčitých tepen) se nemění při chirurgické terapii, avšak výrazně se zhoršuje při PCI. Tento závěr odpovídá i představě, že katetrizační terapie nemůže $\mathrm{z}$ podstaty věci „ošetřit" celé povodí difuzně postižených věnčitých tepen, avšak našití bypassů může vést sice jen $\mathrm{k}$ přechodnému, avšak přesto určitému řešení ve smyslu účinné revaskularizace.

Problematice lékových stentů se na stránkách odborného tisku a v rámci kongresů $\mathrm{v}$ posledních letech věnovalo mnoho prostoru a času. Přes všechna nenaplněná očekávání i nové komplikace, které s jejich používáním souvisejí, je třeba znovu zdůraznit, že Evropa i rozvinutý svět se pohnuly přinejmenším $\mathrm{k}$ nadpoloviční penetraci lékových stentů. $\mathrm{K}$ té máme u nás velmi daleko a je nepochybné, že tímto směrem bychom měli rovněž jít. $V$ této souvislosti je zajímavé poukázat i na farmakoterapii, jež doprovází intervenční 
výkony. Ačkoli se především na poli antitrombotické terapie provedla $\mathrm{v}$ posledních letech celá řada velkých studií, přesto se naše klinická praxe mění jen velmi pomalu.

Velkou šanci pro intervenční kardiology spatřuji v nekoronárních intervencích. Některé z nich si již našly místo v naší klinické praxi (uzávěry PFO a ASD), jiné jsou spíše na ústupu (valvuloplastiky), další by se měly provádět více, ale pouze na pracovištích s dlouhodobým zájmem o danou problematiku (PTSMA). Novou skupinu výkonů představují perkutánní implantace bioprotéz do aortální pozice, které se během několika let stanou zřejmě terapeutickým standardem u stále se rozšiřujícího spektra pacientů. Staronovou skupinou výkonů jsou pak intervence na periferních tepnách, které sice vyžadují adekvátní trénink, a v prrípadě karotických intervencí i další důkazy prospěšnosti, avšak představují velmi početnou skupinu výkonů, ve které by intervenční kardiologové mohli zúročit své mnohaleté zkušenosti z intervencí koronárních. Byla by škoda nevyužít této šance do budoucna.

Otázkou, která se celé poslední desetiletí prolíná českou intervenční kardiologií, je vhodnost či nutnost používání přesnějších metod zobrazení či vyšetření významnosti stenóz věnčitých tepen. IVUS i frakční průtoková rezerva mají své oponenty i proponenty a mají i několik společných jmenovatelů: vyšetření je delší, stojí více peněz, je nutné zavést instrumentárium prrímo do věnčité tepny, a v některých případech ani po vyšetření samotném nemůžeme definitivně odpovědět na otázku významnosti vyšetřované léze. $\mathrm{Na}$ druhou stranu nelze bez použití přinejmenším jedné $\mathrm{z}$ uvedených metod udělat $\mathrm{u}$ některých pacientů zásadní rozhodnutí, týkající se například chirurgické revaskularizace u nemocných s hraničním nálezem na kmeni levé věnčité tepny, nebo při identickém postižení všech tří tepen. Pravděpodobnost nesprávného rozhodnutí se blíži téměř $50 \%$. Proto jsem přesvědčen, že daná vyšetření budeme používat čím dál více. $\mathrm{O}$ jejich prospěšnosti máme již dnes nezvratné důkazy. ${ }^{(4)}$

Česká intervenční kardiologie do jisté míry kopíruje trendy v oboru, které můžeme sledovat v rozvinutých zemích západního světa. Každý z uvedených trendů můžeme také chápat jako určitou výzvu pro současnou garnituru intervenčních kardiologů. Je nepochybně lákavou představou, že by se nám podařilo ovlivnit pokrok v našem oboru např́klad takovým způsobem, jak tomu bylo před deseti lety s intervenční léčbou infarktu myokardu.

\section{Literatura}

1. Boden WE, O'Rourke RA, Teo KK, et al. Optimal medical therapy with or without PCI for stable coronary disease. N Engl J Med 2007;356:1503-16.

2. Weintraub WS, Spertus JA, Kolm P, et al. Effect of PCl on quality of life in patients with stable coronary disease. N Engl J Med 2008;359:677-87.

3. Serruys PW, Morice MC, Kappetein P, et al. Percutaneous coronary intervention versus coronary-artery bypass rafting for severe coronary artery disease. N Engl J Med 2009;360:961-72.

4. Tonino PA, DeBruyne P, Pijls N, et al. Fractional flow reserve versus angiography for guiding percutaneous coronary intervention. N Engl J Med 2009;360:292-4. 